\title{
Effect of foliar application of different elicitors on occurrence of pest and diseases during chia (Salvia hispanica $\mathbf{L}$.) cultivation
}

\author{
Prasanna, H.S. ${ }^{1}$, Maruthi Prasad, B.N. ${ }^{2}$, Vishnuvardhana $^{3}$, Shankarappa \\ T.H. ${ }^{4}$, Ugalat, J. ${ }^{5}$, Shivanna, M. $^{6}$
}

Received: 05.03.2021

Revised: 17.04.2021

Accepted: 28.04.2021

\begin{abstract}
Chia is an important medicinal crop with lot of nutritional value in seeds and there is lot of demand to chia seeds grown without any chemical application. In this context, present study was concentrated on foliar application of different elicitors at 25 and 50 days after sowing as effective plant protectants by inducing plant defense response. Both black and white chia plants sprayed with chitosan at $200 \mathrm{ppm}$ were un-affected by any pest and diseases. The plants sprayed with other elicitors like $100 \mathrm{ppm}$ of salicylic acid, methyl jasmonic acid, potassium silicate, $200 \mathrm{ppm}$ of boric acid, humic acid and $5000 \mathrm{ppm}$ of dry yeast and PGPR are less prone to pest and disease attack. Whereas, the maximum pest infestation and disease incidence were noticed in plants sprayed with gibberellic acid (pest -2.38 and $1.93 \%$; disease - $0.89 \%$ in both) and in control (pest - 1.34 and $1.04 \%$; disease -1.34 and $0.74 \%$ ) in black and white chia respectively.
\end{abstract}

Key words: Chia, Chitosan, Elicitor, $\boldsymbol{G A}_{3}$, Methyl Jasmonic Acid, Salicylic Acid

\section{Introduction}

Elicitors are the compounds which triggers/stimulates defense response in plants. Whenever elicitors are sprayed on the plant, the plant assumes that an external invader has come. Hence, plants want to ensure that it strengthened its cell wall. As a result a "signal" is created due to a metabolic stimulus and possible movement intracellularly as well as inter-cellularly and systemically caused by interaction with the elicitor (Baenas et al., 2014). Plants sprayed with elicitors respond quickly through plant membrane receptors by which it induces local resistance and subsequently generate plant molecular response (Aziz et al., 2003). Many authors have described

\section{Author's Address}

${ }^{1 \& 2}$ Department of Plantation, Spices, Medicinal and Aromatic Crops, College of Horticulture, UHS (B) campus, GKVK, Bengaluru, Karnataka, India

${ }^{3}$ Department of Plantation, Spices, Medicinal and Aromatic Crops, University of Horticultural Sciences, Bagalkot, Karnataka, India

${ }^{4}$ Department of Natural Resource Management, College of Horticulture, UHS (B) campus, GKVK, Bengaluru, Karnataka, India

${ }^{5}$ Department of Plant biochemistry, College of Horticulture, UHS (B) campus, GKVK, Bengaluru, Karnataka, India

${ }^{6}$ Department of Soil Science and Applied Chemistry, College of Horticulture, UHS (B) campus, GKVK, Bengaluru, Karnataka, India

E-mail.: prassu.prasanna11@gmail.com that plants activates defence related reaction in response to elicitor action through induction of proteins and enzymes which are involved in oxidative stress protection and also cause rapid death of cells by hypertensive response at the immediate point of exposure to external invaders (Garcia-Brugger et al., 2006). During these processes, reactive oxygen species and reactive nitrogen species are produced and they alerts the plasma membrane of a cell and inflate the ion fluxes i.e, $\mathrm{Cl}^{-}, \mathrm{K}^{+}$efflux and $\mathrm{Ca}^{2+}$ influx which acts as structural defence barriers by activation and de novo biosynthesis of transcription factors which regulate and induce the genes responsible for secondary metabolite production (Smetanska, 2005, Zhao et al., 2005 and Ferrari, 2010). These secondary metabolites are the key components which deter, repel or fight against external invaders. Chia is a new crop to India introduced recently by Central Food Technological Research Institute, (CFTRI) Mysuru. There were no severe pests and diseases recorded in India as for now, but, as the cultivation progresses new pest and diseases may emerge and therefore, use of elicitation technique may be a promising strategy to avoid use of plant protection chemicals since, the people are demanding for residue free food. 


\section{Materials and Methods}

The present study was conducted for both black and white chia in a randomized complete block design with eleven treatments and 3 replications during rabi season of 2018-19 and 2019-20 at Department of Plantation, Spices, Medicinal and Aromatic Crops, College of Horticulture, University of Horticultural Sciences campus, Gandhi Krishi Vignana Kendra, Bengaluru.

The elicitors were applied twice at 25 and 50 days after sowing as foliar spray. The various treatments includes $\mathrm{T}_{1}$ : Chitosan $200 \mathrm{ppm}, \mathrm{T}_{2}$ : Salicylic acid $100 \mathrm{ppm}, \mathrm{T}_{3}$ : Dry yeast $5000 \mathrm{ppm}, \mathrm{T}_{4}$ : Methyl jasmonic acid $100 \mathrm{ppm}, \mathrm{T}_{5}$ : Potassium silicate 100 ppm, $\mathrm{T}_{6}$ : Gibberellic acid 100 ppm, $\mathrm{T}_{7}$ : Kinetin 100 ppm, $\mathrm{T}_{8}$ : Humic acid $200 \mathrm{ppm}, \mathrm{T}_{9}$ : Boric acid $200 \mathrm{ppm}, \mathrm{T}_{10}$ : Plant growth promoting rhizobacteria (PGPR) $5000 \mathrm{ppm}$ and $\mathrm{T}_{11}$ : Control. The chitosan was added to distilled water three days prior to application for complete solubilization. Similarly dry yeast was added to distilled water five days prior to application for the multiplication of beneficial microbes. The PGPR consortia contain Azospirllum, P-solubilizer (Bacillus megaterium) and Pseudomonas fluorescens in the proportion of 1:1:1. The major pests infested the chia were termites (Fig. 1) and ants (Fig. 2). While, the major diseases noticed during the study was begomo virus infection (Fig. 3). The number of plants infested by diseases and pests during the entire cropping period were recorded and percentage infestation was worked out for both the years as well as for pooled data. The data analysis was done by using WASP 2.0 programme developed by Ashok and Pranjali of ICAR Research Complex for Goa (https://ccari.res.in/wasp2.0/index.php) and data was subjected to arcsine transformation.

\section{Results and Discussion}

In black chia, the plants which were sprayed with $\mathrm{GA}_{3}$ at $100 \mathrm{ppm}(3.27 \%)$ were much affected and no plants were infested by any pest in plants sprayed with $200 \mathrm{ppm}$ of chitosan $\left(\mathrm{T}_{1}\right)$ and 100 ppm of methyl jasmonic acid $\left(\mathrm{T}_{4}\right)$ during first year (Table 1). In the second year, more pest infestation $(1.79 \%)$ was seen in plants sprayed with kinetin at $100 \mathrm{ppm}\left(\mathrm{T}_{5}\right)$ which was on par with $\mathrm{GA}_{3}(100$ ppm), control and boric acid (200 ppm) treatments while, the infestation was nil in case of $T_{1}, T_{2}$
(Salicylic acid at $100 \mathrm{ppm}$ ) and $\mathrm{T}_{4}$. Similarly, in case of pooled mean data, the infestation was seen maximum $(2.38 \%)$ in $\mathrm{GA}_{3}$ treatment and nil in case of chitosan and methyl jasmonic acid treatment. With respect to disease incidence, the maximum disease occurrence $(1.49, \quad 1.19$ and $1.34 \%$ respectively) was recorded in the control and no infection was seen in $T_{1}$ and $T_{2}$ in 2018-19, 201920 ( $\mathrm{T}_{4}$ and $\mathrm{T}_{5}$ also) and in pooled mean data. The plants in control maintained statistical parity with plants sprayed with gibberellic acid at $100 \mathrm{ppm}$ $(1.19 \%)$ for maximum disease incidence in second season (Table 1).

Whereas in white chia also, the plants treated with $\mathrm{GA}_{3}$ at $100 \mathrm{ppm}\left(\mathrm{T}_{6}\right)$ recorded maximum pest infestation of 2.38, 1.49 and 1.93 per cent during first, second (at par with control) and in average data over two years respectively (Table 2). Whereas, the plants sprayed with of chitosan (200 $\mathrm{ppm})$ and salicylic acid (100 ppm) recorded zero pest infestation in all the cropping periods. Similarly, the plant sprayed with dry yeast $(5000$ ppm) and methyl jasmonic acid (100 ppm) also recorded zero pest infestation during 2018-19 and 2019-20 respectively. The maximum disease incidence $(0.89 \%)$ was also recorded in plants treated with $100 \mathrm{ppm}$ of $\mathrm{GA}_{3}$ during all the cropping periods (Table 2). Whereas, $\mathrm{T}_{6}$ was on par with $\mathrm{T}_{11}$ and the disease incidence level in control was same as $\mathrm{T}_{6}$ during second year i.e. 0.89 per cent. However, disease incidence was nil in plants elicited with chitosan (200 ppm), dry yeast (5000 ppm), methyl jasmonic acid (100 ppm) and kinetin $(100 \mathrm{ppm})$ throughout the study. Zero disease incidences were also observed in plants treated with salicylic acid (100 ppm) and PGPR (5000 ppm) during 2018-19 and in potassium silicate (100 ppm) and boric acid (200 ppm) during 2019-20. In both black and white chia the pest occurrence and disease incidence was nil in plants sprayed with $200 \mathrm{ppm}$ of chitosan in both the seasons. While, the incidence was very less in case of plants sprayed other elicitors except $\mathrm{GA}_{3}$ and control treatments. Gibberellic acid spray caused the apical dominance (Brian, 1959), further resulted in production of less number of tertiary spikes which caused the sparse canopy which frees up the movement of pests. Whereas the disease incidence was maximum in control since there was no stimuli for the induction of defence response. 
Effect of foliar application of different elicitors

Table 1: Pest infestation and disease incidence recorded during the crop period of black chia

\begin{tabular}{|c|c|c|c|c|c|c|}
\hline \multirow[t]{2}{*}{ Treatments } & \multicolumn{3}{|c|}{ Pest infestation (\%) } & \multicolumn{3}{|c|}{ Disease incidence (\%) } \\
\hline & 2018-19 & $2019-20$ & Pooled & 2018-19 & $2019-20$ & Pooled \\
\hline $\mathbf{T}_{1}:$ Chitosan $200 \mathrm{ppm}$ & $\begin{array}{l}0.00^{\mathrm{c}} \\
(0.00)\end{array}$ & $\begin{array}{l}0.00^{\mathrm{e}} \\
(0.00)\end{array}$ & $\begin{array}{l}0.00^{c} \\
(0.00)\end{array}$ & $\begin{array}{l}0.00^{\mathrm{b}} \\
(0.00)\end{array}$ & $\begin{array}{l}0.00^{\mathrm{b}} \\
(0.00)\end{array}$ & $\begin{array}{l}0.00^{\mathrm{c}} \\
(0.00)\end{array}$ \\
\hline $\mathbf{T}_{\mathbf{2}}:$ Salicylic acid $100 \mathrm{ppm}$ & $\begin{array}{l}0.30^{\mathrm{bc}} \\
(3.13)\end{array}$ & $\begin{array}{l}0.00^{\mathrm{e}} \\
(0.00)\end{array}$ & $\begin{array}{l}0.15^{\mathrm{c}} \\
(2.21)\end{array}$ & $\begin{array}{l}0.00^{\mathrm{b}} \\
(0.00)\end{array}$ & $\begin{array}{l}0.00^{\mathrm{b}} \\
(0.00)\end{array}$ & $\begin{array}{l}0.00^{\mathrm{c}} \\
(0.00)\end{array}$ \\
\hline $\mathbf{T}_{\mathbf{3}}$ : Dry yeast $5000 \mathrm{ppm}$ & $\begin{array}{l}0.30^{\mathrm{bc}} \\
(3.13)\end{array}$ & $\begin{array}{l}0.30^{\mathrm{de}} \\
(3.13)\end{array}$ & $\begin{array}{l}0.30^{\mathrm{c}} \\
(3.13)\end{array}$ & $\begin{array}{l}0.00^{\mathrm{b}} \\
(0.00)\end{array}$ & $\begin{array}{l}0.30^{\mathrm{b}} \\
(3.13)\end{array}$ & $\begin{array}{l}0.15^{\mathrm{c}} \\
(2.21)\end{array}$ \\
\hline $\mathbf{T}_{\mathbf{4}}:$ Methyl Jasmonic acid 100 ppm & $\begin{array}{l}0.00^{\mathrm{c}} \\
(0.00)\end{array}$ & $\begin{array}{l}0.00^{\mathrm{e}} \\
(0.00)\end{array}$ & $\begin{array}{l}0.00^{\mathrm{c}} \\
(0.00)\end{array}$ & $\begin{array}{l}0.30^{\mathrm{b}} \\
(3.13)\end{array}$ & $\begin{array}{l}0.00^{\mathrm{b}} \\
(0.00)\end{array}$ & $\begin{array}{l}0.15^{\mathrm{c}} \\
(2.21)\end{array}$ \\
\hline $\mathbf{T}_{\mathbf{5}}:$ Potassium silicate $100 \mathrm{ppm}$ & $\begin{array}{l}0.30^{\mathrm{bc}} \\
(3.13)\end{array}$ & $\begin{array}{l}0.60^{\text {cde }} \\
(4.42)\end{array}$ & $\begin{array}{l}0.45^{\mathrm{c}} \\
(3.83)\end{array}$ & $\begin{array}{l}0.60^{\mathrm{b}} \\
(4.42)\end{array}$ & $\begin{array}{l}0.00^{\mathrm{b}} \\
(0.00)\end{array}$ & $\begin{array}{l}0.30^{\mathrm{c}} \\
(3.13)\end{array}$ \\
\hline $\mathbf{T}_{\mathbf{6}}:$ Gibberellic acid $100 \mathrm{ppm}$ & $\begin{array}{l}3.27^{\mathrm{a}} \\
(10.42)\end{array}$ & $\begin{array}{l}1.49^{\mathrm{ab}} \\
(7.01)\end{array}$ & $\begin{array}{l}2.38^{\mathrm{a}} \\
(8.88)\end{array}$ & $\begin{array}{l}0.60^{\mathrm{b}} \\
(4.42)\end{array}$ & $\begin{array}{l}1.19^{\mathrm{a}} \\
(6.26)\end{array}$ & $\begin{array}{l}0.89^{\mathrm{ab}} \\
(5.42)\end{array}$ \\
\hline $\mathbf{T}_{7}:$ Kinetin $100 \mathrm{ppm}$ & $\begin{array}{l}0.89^{\mathrm{bc}} \\
(5.42)\end{array}$ & $\begin{array}{l}1.79^{\mathrm{a}} \\
(7.68)\end{array}$ & $\begin{array}{l}1.34^{b} \\
(6.65)\end{array}$ & $\begin{array}{l}0.60^{b} \\
(4.42)\end{array}$ & $\begin{array}{l}0.30^{\mathrm{b}} \\
(3.13)\end{array}$ & $\begin{array}{l}0.45^{\text {bc }} \\
(3.83)\end{array}$ \\
\hline $\mathbf{T}_{\mathbf{8}}:$ Humic acid $200 \mathrm{ppm}$ & $\begin{array}{l}0.89^{\mathrm{bc}} \\
(5.42)\end{array}$ & $\begin{array}{l}0.60^{\text {cde }} \\
(4.42)\end{array}$ & $\begin{array}{l}0.74^{\mathrm{b}} \\
(4.95)\end{array}$ & $\begin{array}{l}0.60^{\mathrm{b}} \\
(4.42)\end{array}$ & $\begin{array}{l}0.30^{\mathrm{b}} \\
(3.13)\end{array}$ & $\begin{array}{l}0.45^{\mathrm{bc}} \\
(3.83)\end{array}$ \\
\hline $\mathbf{T}_{\mathbf{9}}:$ Boric acid $200 \mathrm{ppm}$ & $\begin{array}{l}0.60^{\mathrm{bc}} \\
(4.42)\end{array}$ & $\begin{array}{l}0.89^{\mathrm{abcd}} \\
(5.42)\end{array}$ & $\begin{array}{l}0.74^{\mathrm{b}} \\
(4.95)\end{array}$ & $\begin{array}{l}0.60^{\mathrm{b}} \\
(4.42)\end{array}$ & $\begin{array}{l}0.30^{\mathrm{b}} \\
(3.13)\end{array}$ & $\begin{array}{l}0.45^{\mathrm{bc}} \\
(3.83)\end{array}$ \\
\hline $\mathbf{T}_{\mathbf{1 0}}$ : PGPR $5000 \mathrm{ppm}$ & $\begin{array}{l}0.89^{\mathrm{bc}} \\
(5.42)\end{array}$ & $\begin{array}{l}0.60^{\text {cde }} \\
(4.42)\end{array}$ & $\begin{array}{l}0.74^{\mathrm{b}} \\
(4.95)\end{array}$ & $\begin{array}{l}0.30^{\mathrm{b}} \\
(3.13)\end{array}$ & $\begin{array}{l}0.30^{\mathrm{b}} \\
(3.13)\end{array}$ & $\begin{array}{l}0.30^{\mathrm{c}} \\
(3.13)\end{array}$ \\
\hline $\mathbf{T}_{\mathbf{1 1}}:$ Control & $\begin{array}{l}1.49^{\mathrm{b}} \\
(7.01)\end{array}$ & $\begin{array}{l}1.19^{\mathrm{abc}} \\
(6.26)\end{array}$ & $\begin{array}{l}1.34^{\mathrm{b}} \\
(6.65)\end{array}$ & $\begin{array}{l}1.49^{\mathrm{a}} \\
(7.01)\end{array}$ & $\begin{array}{l}1.19^{\mathrm{a}} \\
(6.26)\end{array}$ & $\begin{array}{l}1.34^{\mathrm{a}} \\
(6.65)\end{array}$ \\
\hline SE $\mathbf{m} \pm$ & 0.36 & 0.24 & 0.24 & 0.26 & 0.23 & 0.17 \\
\hline CD at $5 \%$ & 1.07 & 0.71 & 0.69 & 0.75 & 0.67 & 0.48 \\
\hline $\mathbf{C V}$ & 77.07 & 61.23 & 80.04 & 96.17 & 111.79 & 102.62 \\
\hline
\end{tabular}

Note: Figures in parentheses are arcsine transformed values

Means followed by same letter in the column do not differ significantly at 5 per cent level by DMRT

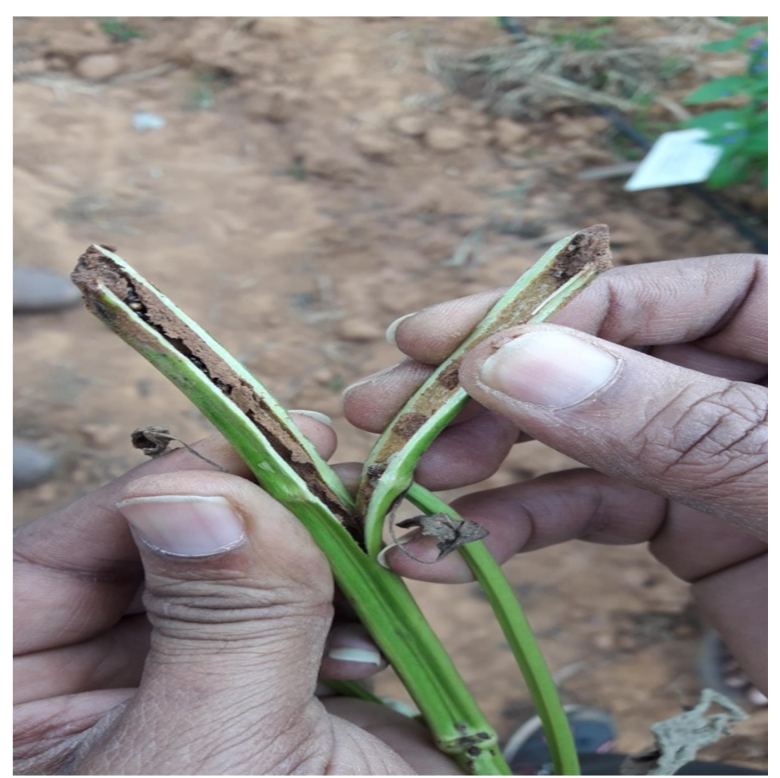

Figure 1: Termite's damage
Elicitors induce the plant immune response by activation of signal cascade (Patel et al., 2020). The secondary metabolites produced in plants due to various signaling molecules in response to elicitor application stimulate the defense action (Dzhavakhiya and Shcherbakova 2007). Hence, elicitation is one promising approach to enhance the resistance of plants against various diseases and insect attack. Chitosan activates the various enzymes to detoxify reactive oxygen species in which hydrogen peroxide and nitric oxide are also said to be involved in signalling of chitosan which helped in boosting the plant immunity (Hadwiger, 2013). It is also suspected to interact with chromatin and directly affect the gene expression (Hadwiger, 2015). Salicylic acid is a stress messenger induces hypersensitive responses and helps the plant to escape from external invaders (RodasJunco et al., 2020). The phenylalanine 
Prasanna et al.

Table 2: Pest infestation and disease incidence recorded during white chia growing period

\begin{tabular}{|c|c|c|c|c|c|c|}
\hline \multirow[t]{2}{*}{ Treatments } & \multicolumn{3}{|c|}{ Pest infestation (\%) } & \multicolumn{3}{|c|}{ Disease incidence (\%) } \\
\hline & 2018-19 & 2019-20 & Pooled & 2018-19 & 2019-20 & Pooled \\
\hline $\mathbf{T}_{1}:$ Chitosan $200 \mathrm{ppm}$ & $\begin{array}{l}0.00^{\mathrm{c}} \\
(0.00)\end{array}$ & $\begin{array}{l}0.00^{\mathrm{c}} \\
(0.00) \\
\end{array}$ & $\begin{array}{l}0.00^{\mathrm{c}} \\
(0.00) \\
\end{array}$ & $\begin{array}{l}0.00^{\mathrm{b}} \\
(0.00) \\
\end{array}$ & $\begin{array}{l}0.00^{\mathrm{b}} \\
(0.00)\end{array}$ & $\begin{array}{l}0.00^{\mathrm{c}} \\
(0.00)\end{array}$ \\
\hline $\mathbf{T}_{\mathbf{2}}:$ Salicylic acid $100 \mathrm{ppm}$ & $\begin{array}{l}0.00^{\mathrm{c}} \\
(0.00)\end{array}$ & $\begin{array}{l}0.00^{\mathrm{c}} \\
(0.00) \\
\end{array}$ & $\begin{array}{l}0.00^{\mathrm{c}} \\
(0.00) \\
\end{array}$ & $\begin{array}{l}0.00^{b} \\
(0.00)\end{array}$ & $\begin{array}{l}0.30^{b} \\
(3.13)\end{array}$ & $\begin{array}{l}0.15^{\mathrm{c}} \\
(2.21)\end{array}$ \\
\hline $\mathbf{T}_{\mathbf{3}}$ : Dry yeast $5000 \mathrm{ppm}$ & $\begin{array}{l}0.00^{\mathrm{c}} \\
(0.00)\end{array}$ & $\begin{array}{l}0.30^{\mathrm{bc}} \\
(3.13) \\
\end{array}$ & $\begin{array}{l}0.15^{\mathrm{c}} \\
(2.21) \\
\end{array}$ & $\begin{array}{l}0.00^{\mathrm{b}} \\
(0.00) \\
\end{array}$ & $\begin{array}{l}0.00^{\mathrm{b}} \\
(0.00)\end{array}$ & $\begin{array}{l}0.00^{c} \\
(0.00)\end{array}$ \\
\hline $\mathbf{T}_{\mathbf{4}}$ : Methyl Jasmonic acid 100 ppm & $\begin{array}{l}0.30^{\mathrm{c}} \\
(3.13) \\
\end{array}$ & $\begin{array}{l}0.00^{\mathrm{c}} \\
(0.00) \\
\end{array}$ & $\begin{array}{l}0.15^{\mathrm{c}} \\
(2.21)\end{array}$ & $\begin{array}{l}0.00^{b} \\
(0.00)\end{array}$ & $\begin{array}{l}0.00^{b} \\
(0.00)\end{array}$ & $\begin{array}{l}0.00^{\mathrm{c}} \\
(0.00)\end{array}$ \\
\hline $\mathbf{T}_{5}:$ Potassium silicate $100 \mathrm{ppm}$ & $\begin{array}{l}0.30^{\mathrm{c}} \\
(3.13) \\
\end{array}$ & $\begin{array}{l}0.60^{\text {bc }} \\
(4.42)\end{array}$ & $\begin{array}{l}0.45^{\mathrm{c}} \\
(3.83) \\
\end{array}$ & $\begin{array}{l}0.30^{b} \\
(3.13) \\
\end{array}$ & $\begin{array}{l}0.00^{b} \\
(0.00)\end{array}$ & $\begin{array}{l}0.15^{\mathrm{c}} \\
(2.21)\end{array}$ \\
\hline $\mathbf{T}_{\mathbf{6}}:$ Gibberellic acid $100 \mathrm{ppm}$ & $\begin{array}{l}2.38^{\mathrm{a}} \\
(8.88) \\
\end{array}$ & $\begin{array}{l}1.49^{\mathrm{a}} \\
(7.01) \\
\end{array}$ & $\begin{array}{l}1.93^{\mathrm{a}} \\
(8.00) \\
\end{array}$ & $\begin{array}{l}0.89^{\mathrm{a}} \\
(5.41) \\
\end{array}$ & $\begin{array}{l}0.89^{\mathrm{a}} \\
(5.41) \\
\end{array}$ & $\begin{array}{l}0.89^{\mathrm{a}} \\
(5.41)\end{array}$ \\
\hline $\mathbf{T}_{7}$ : Kinetin 100 ppm & $\begin{array}{l}0.60^{\text {bc }} \\
(4.42) \\
\end{array}$ & $\begin{array}{l}0.60^{\mathrm{bc}} \\
(4.42) \\
\end{array}$ & $\begin{array}{l}0.60^{\mathrm{bc}} \\
(4.42) \\
\end{array}$ & $\begin{array}{l}0.00^{\mathrm{b}} \\
(0.00) \\
\end{array}$ & $\begin{array}{l}0.00^{b} \\
(0.00) \\
\end{array}$ & $\begin{array}{l}0.00^{\mathrm{c}} \\
(0.00)\end{array}$ \\
\hline $\mathbf{T}_{\mathbf{8}}:$ Humic acid 200 ppm & $\begin{array}{l}0.30^{\mathrm{c}} \\
(3.13) \\
\end{array}$ & $\begin{array}{l}0.60^{\mathrm{bc}} \\
(4.42) \\
\end{array}$ & $\begin{array}{l}0.45^{\mathrm{c}} \\
(3.83) \\
\end{array}$ & $\begin{array}{l}0.30^{b} \\
(3.13) \\
\end{array}$ & $\begin{array}{l}0.30^{b} \\
(3.13) \\
\end{array}$ & $\begin{array}{l}0.30^{c} \\
(3.13)\end{array}$ \\
\hline $\mathbf{T}_{\mathbf{9}}$ : Boric acid 200 ppm & $\begin{array}{l}0.60^{b c} \\
(4.42)\end{array}$ & $\begin{array}{l}0.30^{\text {bc }} \\
(3.13)\end{array}$ & $\begin{array}{l}0.45^{\mathrm{c}} \\
(3.83)\end{array}$ & $\begin{array}{l}0.30^{b} \\
(3.13)\end{array}$ & $\begin{array}{l}0.00^{b} \\
(0.00)\end{array}$ & $\begin{array}{l}0.15^{\mathrm{c}} \\
(2.21)\end{array}$ \\
\hline $\mathbf{T}_{\mathbf{1 0}}:$ PGPR $5000 \mathrm{ppm}$ & $\begin{array}{l}0.60^{b c} \\
(4.42)\end{array}$ & $\begin{array}{l}0.30^{\text {bc }} \\
(3.13)\end{array}$ & $\begin{array}{l}0.45^{\mathrm{c}} \\
(3.83)\end{array}$ & $\begin{array}{l}0.00^{b} \\
(0.00)\end{array}$ & $\begin{array}{l}0.30^{b} \\
(3.13)\end{array}$ & $\begin{array}{l}0.15^{\mathrm{c}} \\
(2.21)\end{array}$ \\
\hline $\mathbf{T}_{11}$ : Control & $\begin{array}{l}1.19^{b} \\
(6.26)\end{array}$ & $\begin{array}{l}0.89^{\mathrm{ab}} \\
(5.41) \\
\end{array}$ & $\begin{array}{l}1.04^{b} \\
(5.86) \\
\end{array}$ & $\begin{array}{l}0.60^{\mathrm{ab}} \\
(4.42) \\
\end{array}$ & $\begin{array}{l}0.89^{\mathrm{a}} \\
(5.41)\end{array}$ & $\begin{array}{l}0.74^{b} \\
(4.93)\end{array}$ \\
\hline SE $\mathbf{m} \pm$ & 0.25 & 0.24 & 0.17 & 0.19 & 0.16 & 0.12 \\
\hline CD & 0.73 & 0.72 & 0.50 & 0.55 & 0.46 & 0.34 \\
\hline $\mathbf{C V}$ & 75.41 & 91.30 & 83.13 & 148.90 & 110.55 & 125.71 \\
\hline
\end{tabular}

Note: Figures in parentheses are arcsine transformed values

Means followed by same letter in the column do not differ significantly at 5 per cent level by DMRT

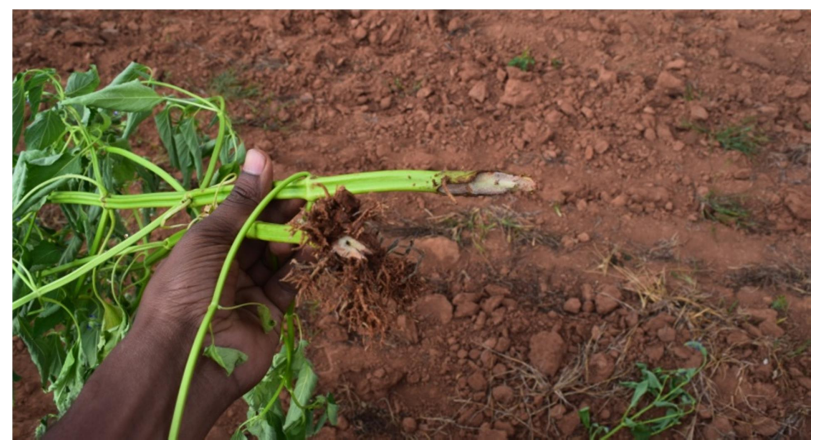

Figure 2: Ant's damage

mmonia lyase is known to be involved in defense reaction of a plant due to de novo transcription of genes which can be activated by methyl jasmonate (Chen et al., 2017). Potassium silicate provides strength to plant and also resist the external invaders and minimizes the pest and disease attack. Some of the studies related to effect of elicitors on plant defence are listed here. Chitosan in tomato (Cho et al., 2011 and Tavallali et al., 2008) and in

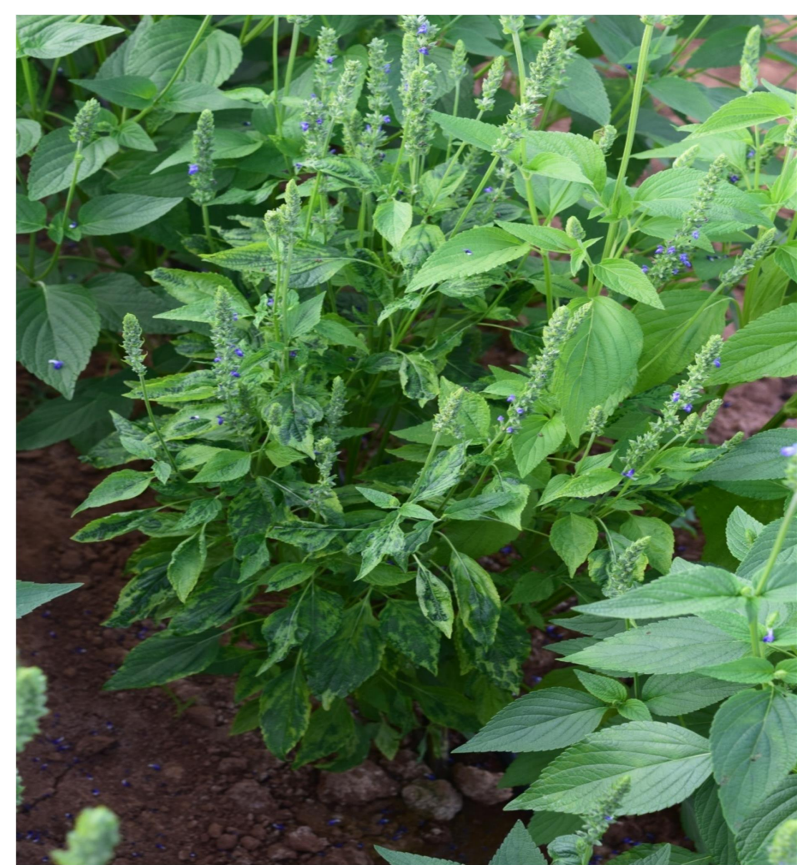

Figure 3: Begomo virus affected plant. 


\section{Effect of foliar application of different elicitors}

paddy, radish, tobacco, groundnut and Pea (Maksimov et al., 2003). Salicylic acid in tomato (Esmailzadeh and Soleimani, 2008; GarciaMagallon et al., 2002; Peng et al., 2004; Tavallali et al., 2008), pea (Katoch, 2005) and Bhendi (Vimala and Suriachandraselvan, 2009). Methyl jasmonic acid in Brassica (Xu et al., 2018), Brinjal (Mandal, 2010) and cabbage (Perez-Balibrea et al., 2011). Humic acid in soyabean (Abdel-Monaim et al., 2011). Potassium silicate in wheat (Mehdi et al., 2007), strawberry (Kanto et al., 2006) and in chilli etc. (Dogramaci et al., 2013).

\section{Conclusion}

Elicitation is an important strategy to induce resistance in chia which reduces the use of plant protection chemicals by reducing the pest and pathogen populations. In both black chia, foliar spray with chitosan at $200 \mathrm{ppm}$ showed 100 per

\section{References}

Abdel-Monaim, M. F., Ismail, M. E. and Morsy K. M. 2011. Induction of systematic resistance in soybean plants against Fusarium wilt disease by seed treatment with benzothiadiazole and humic acid. Notulae Scientia Biologicae, 3(2): 80-89.

Ashok, K. J. and Pranjali, T. https://ccari.res.in/wasp2.0/index.php

Aziz, A., Poinssot, B., Daire, X., Adrian, M., Bezier, A., Lambert, B., Joubert, J. M. and Pugin, A. 2003. Laminarin elicits defense responses in grapevine and induces protection against Botrytis cinerea and Plasmopara viticola. Molecular Plant-Microbe Interactions, 16(12): 1118-1128.

Baenas, N., Garcia-Viguera, C. and Moreno, D. A. 2014. Elicitation: A tool for enriching the bioactive composition of foods. Molecules, 19: 13541-13563.

Brian, P. W. 1959. Effects of gibberellins on plant growth and development. Biological Reviews, 34(1): 37-77.

Dogramaci, M., Arthurs, S. P., Chen, J. and Osborne, L. 2013. Silicon applications have minimal effects on Scirtothrips dorsalis (Thysanoptera: Thripidae) populations on pepper plant, Capsicum annum L. Florida Entomologist, 48-54.

Xu, L., Yang, H., Ren, L., Chen, W., Liu, L., Liu, F., Zeng, L., Yan, R., Chen, K. and Fang, X. 2018. Jasmonic acidmediated aliphatic glucosinolate metabolism is involved in clubroot disease development in Brassica napus L. Frontiers in Plant Science, 9: 750. cent resistance to any pest and diseases and the plants sprayed with $100 \mathrm{ppm}$ of salicylic acid, methyl jasmonic acid and potassium silicate was less to prone pest and disease attack. However for pooled mean, maximum pest infestation was recorded in plants sprayed with $100 \mathrm{ppm}$ of $\mathrm{GA}_{3}$ while the maximum disease occurrence was seen in untreated plants. In white chia, the plants sprayed with $200 \mathrm{ppm}$ of chitosan and $100 \mathrm{ppm}$ of salicylic acid showed 100 per cent resistance to pest infestation in all cropping periods while, the plats sprayed with $\mathrm{GA}_{3}$ recorded maximum pest infestation. Whereas, plants sprayed with $200 \mathrm{ppm}$ of chitosan, $100 \mathrm{ppm}$ of methyl jasmonic acid, kinetin and $5000 \mathrm{ppm}$ of dry yeast recorded zero disease incidence while, the plants treated with $\mathrm{GA}_{3}$ $(100 \mathrm{ppm})$ and in control recorded maximum disease occurrence in all the cropping periods.

Dzhavakhiya, V. G. and Shcherbakova, L. A. 2007. Creation of disease-resistant plants by gene engineering. Comprehensive and Molecular Phytopathology, 439-466.

Ferrari, S. 2010. Biological elicitors of plant secondary metabolites: Mode of action and use in the production of nutraceutics. In Bio-Farms for Nutraceuticals, 698:152166.

Garcia-Brugger, A., Lamotte, O., Vandelle, E., Bourque, S., Lecourieux, D., Poinssot, B., Wendehenne, D. and Pugin, A. 2006. Early signaling events induced by elicitors of plant defenses. Molecular Plant-Microbe Interactions, 19: 711-724.

Garcia-Magallon, E., Rojas-Duarte, A., Benavides-Mendoza, A., Ramirez-Godina, F. and Banuelos-Herrera, L. 2002. Application of benzoic acid in foliar form to the cultivation of Lilium $c v$. Dreamland. Memoria del XIX Congreso Nacional de Fitogenética. Saltillo, Mexico: Sociedad Mexicana de Fitogenetica, p.72.

Chen, Y., Li, F., Tian, L., Huang, M., Deng, R., Li, X., Chen, W., Wu, P., Li, M., Jiang, H. and Wu, G. 2017. The phenylalanine ammonia lyase gene LjPAL1 is involved in plant defense responses to pathogens and plays diverse roles in Lotus japonicus-rhizobium symbioses. Molecular Plant-Microbe Interactions, 30(9): 739-753.

Hadwiger, L. A. 2013. Multiple effects of chitosan on plant systems. Plant Science, 208: 42-49.

Hadwiger, L. A. 2015. Anatomy of a non host disease resistance response of pea to Fusarium solani PR gene 


\section{Prasanna et al.}

elicitation via DNase, chitosan and chromatin alterations. Frontiers in Plant Science, 12: 347-350.

Kanto, T., Miyoshi, A., Ogawa, T., Maekawa, K. and Aino, M. 2006. Suppressive effect of liquid potassium silicate on powdery mildew of strawberry in soil. Journal of General Plant Pathology, 72(3): 137-142.

Katoch, R. 2005. Effect of elicitors and E. polygoni inoculation on the activity of phenol metabolizing enzymes in garden pea (Pisum sativum L.). Indian Journal of Agricultural Biochemistry, 18(2): 87-91.

Rodas-Junco, B. A., Nic-Can, G. I., Munoz-Sanchez, A. and Hernandez-Sotomayor, S.M. 2020. Phospholipid signaling is a component of the salicylic acid response in plant cell suspension cultures. International Journal of Molecular Sciences, 21(15), p.5285.

Cho, Y. H., Choi, G. J., Kim, B. S., Jang, K. S., Yoon, M. Y., Park, M. S. and Kim, J. C. 2011. Control of late blight of tomato and potato by oilgochitosan. Research in Plant Disease, 17(2): 129-135.

Maksimov, I. V., Cherepanova E. A., Khairullin R. M. 2003. 'Chitin-specific' peroxidases

plants. Biochemistry, 68(1):111-115.

Mandal, S. 2010. Induction of phenolics, lignin and key defense enzymes in eggplant (Solanum melongena L.) roots in response to elicitors. African Journal of Biotechnology, 9(47): 8038-8047.

Mehdi, S. M., Sarfraz, M. and Shah, S. A. 2007. Response of wheat to applied supplemental potassium in saline sodic soil. Journal of Biological Sciences, 7: 823-826.
Patel, Z. M., Mahapatra, R. and Jampala, S. S. M. 2020. Role of fungal elicitors in plant defense mechanism. In Molecular Aspects of Plant Beneficial Microbes in Agriculture, Academic Press, 143-158.

Peng, J., Deng, X., Jia, S., Huang, J., Miao, X., \& Huang, Y. 2004. Role of salicylic acid in tomato defense against cotton bollworm, Helicoverpa armigera Hubner. Zeitschrift für Naturforschung C,59(11-12), 856-862.

Perez-Balibrea, S., Moreno, D. A. and Garcia-Viguera, C. 2011. Improving the phytochemical composition of broccoli sprouts by elicitation. Food Chemistry, 129(1): $35-44$.

Esmailzadeh, M. and Soleimani, M. J. 2008. Exogenous applications of salicylic acid for inducing systematic acquired resistance against tomato stem canker disease. Journal of Biological Science, 8.

Smetanska, I. 2005. Impact of elicitors on glucosinolate production in plants and exudates of turnip (Brassica rapa). Ph.D. Thesis, University of Berlin, Germany.

Tavallali, V., Karimi, S., Mohammadi, S. and Hojati, S. 2008. Effects of $\beta$-aminobutyric acid on the induction of resistance to Penicillium italicum. World Applied Sciences Journal, 5(3): 345-351.

Vimala, R. and Suriachandraselvan, M. 2009. Induced resistance in bhendi against powdery mildew by foliar application of salicylic acid. Journal of Biopesticides, 2(1): 111-114.

Zhao, J., Davis, L. C. and Verpoorte, R. 2005. Elicitor signal transduction leading to production of plant secondary metabolites. Biotechnology Advances, 23: 283-333. 